\title{
Need Analysis and Curriculum Design in Business English
}

\author{
Geng Chunling $^{1 *}$ \\ ${ }^{1}$ Inner Mongolia University for the Nationalities, Inner Mongolia, China \\ * Geng Chunking, E-mail: gckalice@163.com
}

\begin{abstract}
Business English education, which serves as a branch of ESP (English for Specific Purposes) is of great importance. With the development of market economy and the further strengthening of economic globalization, Business English is receiving more and more attention and is showing unprecedented momentum. And in the world of Business English, need analysis is at the heart of planning and instructional design. Yet, designing a Business English course requires collaboration among several concerned stakeholders, including students, subject teachers, institutional administrators and Business English teachers themselves. This article gives a detailed description of Business English and need analysis, analyzes the importance of need analysis to syllabus design based on need analysis.
\end{abstract}

\section{Keywords}

need analysis, curriculum design, Business English

\section{Introduction}

English language plays a very crucial role as the predominant tool for communication in the global community. There is no language as influential as English, which has become a common language among people from different countries and in various fields from politics, foreign affairs, cultures, and commerce to technology. English is now used by approximately four billion people on earth, including 400 million native speakers. It is a "contact language" between persons who share neither a common native language nor a common culture, and for whom English is the chosen foreign language of communication. In fact, English has become an international language and is widely used as a medium for understanding and exchanging ideas among people all over the world.

\section{Literature Review}

\subsection{Business English}

As a branch of English for Specific Purposes, Business English is difficult to define and limit in linguistic terms. It is a study of English fundamentals applied to sentences containing the vocabulary and concepts of business (Ruth, 1980). Business English must be seen in the overall context of ESP as it shares the important elements of needs analysis, syllabus design, and materials selection and development which are common to all fields of work in ESP. As with other varieties of ESP, Business English implies the definition of a specific language corpus and emphasis on particular kinds of 
communication in a specific context, the business context (Ellis \& Johnson, 1994, p. 3).

\subsection{Need Analysis}

The idea of need analysis has been developed with the upsurge of interest in BE. ESP researchers lay emphasis on need analysis which has existed in the world of language education for two or three decades.

Need is most commonly referred to as the discrepancy or gap between what is the present state of affairs in regard to the group and what should be desired state. There are different distinctions of needs, such as objective needs vs. subjective needs; target needs vs. learning needs and felt needs vs. perceived needs.

Hutchinson and Waters divides needs into target needs and learning needs. Target needs are an umbrella term which refers to the knowledge and skills which the learners should master in target situation. Specifically, target needs include necessities, wants and lacks. Necessities refer to what the learners have to know in order to function effectively in the target situation. Wants refer to the students' needs based on the requirements of the target situation and lacks refer to the gap between what the learners have already known and the necessities. Learning needs, which include the learners' knowledge, skills, strategies and motivations, refer to what the learners have to do in order to master the knowledge and skills in the target situation (Hutchinson \& Waters, 1987).

Need analysis can be used, for example, to identify students' instruction needs; as certain weaknesses in students' achievements; provide information on in-service need; determine where deficits exist so that they can be addressed; and identify areas for expenditure and educational development (Cohen et al., 2000, p. 90). Needs analysis plays a vital role in developing English for specific purposes curriculum. It is the process of establishing what and how a course will run. Need analysis refers to the technologies and methods used to research needs by means of introspect, interview, observation, questionnaire, etc., which has been widely used in education, economy and trade, manufacturing, service, etc., (Chen Binbin, 2009, p. 126).

Grier attempted to integrate needs assessment with curriculum development $(2005$, p. 65). He states that: "In order to develop curricula of quality, developers must have valid information on which to base their curricular decisions. The various methods of needs assessment are valuable tools that provide curriculum developers with this information. By incorporating needs assessments in their curricular decisions, curriculum developers can select options that benefit both the learners and society".

\subsection{Importance of Need Analysis to Curriculum Design}

Need analysis plays an important role in curriculum design for it largely determines the goal and content of the course being designed and it is closely linked to curriculum and occupies an important place in curriculum. In the field of foreign language teaching, need analysis is the preliminary step in curriculum design and is considered as a prerequisite. Effective curricula often lies in need analysis. Need analysis is a powerful tool that helps clarify and validate true needs. It enables educators to shape the curriculum development that bases the content of language courses on the communication needs, 
wants and interests of the learners (Lepetit \& Cichocki, 2005).

Since Business English should be categorized under the title of ESP, the research on Business English should follow the general theoretical framework of ESP, whose most important part is the need analysis. As the starting point of every course, it is of utmost importance for Business English course design and its proper application can result into a focused course. A lot of courses are designed on the basis of objective needs perceived by course designers or concluded from social needs, without considering students' subjective needs. But the learners in BE courses are thinking beings that have their own needs which will affect the whole process of BE learning. Nunan (1988) indicate three main purposes that NA serves in terms of general curriculum processes as follows: NA remains an important first step of curriculum development, serving as a key source of input for decisions to be made with respect to objectives, student placement, content specification and methodology. It also provides a means of obtaining wider input into the implementation of a language program. It can provide data for reviewing and evaluating an existing program for the purpose of improving curricula. Accordingly, NA assures a flexible, responsive curriculum rather than a fixed, linear curriculum determined in advance by administrators or instructors. When learners know that educators understand and want to address their needs and interests, they are motivated to continue to learn.

Needs analysis in Business English is a must because most of the learners are aware of what they need. By conducting needs analysis, teachers can not only collect factual information for the purpose of setting broad goals related to language content; but also gather information about learners that can be used to guide the learning process once it's under way. Needs analysis is not a static process, but a dynamic one. It entails many procedures and a lot of efforts to accomplish. The learner's needs analysis is the primary but the fundamental stage of learner-centered curriculum design, without which, all efforts will turn out to be in vain. Therefore, as a branch of ESP, needs analysis of BE is of vital importance for Business English.

\section{Curriculum Design Based on Need Analysis}

\subsection{Learning Needs}

In traditional curriculum designs, usually, the purpose is defined according to state policy or designers' own understanding of the educational requirement. Focus is on what are available for learners, what teachers can offer to learners and what the learners have to acquire, but few is considered about what the learners themselves want. The inefficiency of a foreign language course is ascribed to improper goals set in the language curriculum and failure of taking into account the curriculum consumer-learner in a specific institution. Thus the identification of learners' needs is a fundamental step in school-based curriculum development. A learner-centered curriculum design fully realizes the importance of the learner's role in teaching activities, and places the learner's needs, not only what he has to acquire, but also what he wants to acquire, at the central part of the whole designing process. According to Richards, needs analysis has three functions as "it provides a means of obtaining wider input into the content, 
design and implementation of a language programmer; it can be used in developing goals, objectives and content; and it can provide data for reviewing and evaluating an existing programmer" (Richards, 1984, p. 5). Bindley divides the learner's needs into objective and subjective needs. Objective needs are those which can be checked by teachers with information about learner's age, education background, learning experience, language proficiency level, etc.; while subjective needs are those which are necessary for the learner in target environment, those which the learner still lacks and which the learner expect or desire to acquire (Nunan, 2005, p. 44). After analyzing target needs which show what the learners need to do in the target situation - there arise the problem how the learners can proceed successfully from lacks to necessities or wants to obtain the knowledge and abilities. Yet, the whole process of $\mathrm{BE}$ is concerned not with knowing, but with learning. So the needs in the process of learning should also be taken into consideration. Hutchinson and Waters put forward the concept-learning needs and its analysis, which have been proved to be fairly useful in practice.

Out of various reasons, learners may be greatly motivated in the teaching process, but may completely lose interest in the same material in a BE classroom. That is, the target situation unnecessarily indicates what is needed or useful in the $\mathrm{BE}$ learning situation. As a result, the $\mathrm{BE}$ course designers and teachers need to analyze the learners' learning needs according to their motivation, the conditions of the learning situation, and their existing knowledge and skills. So in order to offer a better BE course that can meet the needs of the students exactly, it is necessary to take learner's needs into consideration when designing the Business English course.

\subsection{Teaching Goals and Objectives}

Goals are defines as general statements concerning desirable and attainable program purposes and aims based on perceived language and situation need (Brown, 1995). And the goals of Business English course are to inspire the learning interest of students and help students cultivate self-confidence, thus fully developing their competence of autonomous learning. After learning the course, it's unnecessary for the students to get the on-job basic training when employed by the companies.

Teaching objective refers to the requirements that should be met through the teaching process. It is the particular knowledge, behaviors, and/or skills that the learner will be expected to know or perform at the end of a course or program. Direct assessment of the objectives at the end of a course will provide evidence if the teaching objectives have been achieved, or have not been achieved. The orientation of the teaching objective is critical in the whole teaching process, which determines the teaching activities It is the starting as well as ending point of teaching activities, which has both orientation function and adjustment function. So the teacher should be clear of the orientation of a course before starting the course, in order that he will not mistake an BE course for a specialized course taught in English.

One of the most important objectives of modern education is to enable the students to pursue life-long education on their own. To have a better understanding of Business English teaching, it is necessary to make the orientation of the course clear first. Teaching Business English is not about using English to teach business but about teaching the students to express what they have learned on their specialty in 
English, build up system of business-related terms, and master the structure, linguistic features and expression rules of business-related texts. The emphasis should be put on the English rather than specialty itself.

\subsection{Teaching Method in the Teaching Process}

Every method or approach, since it exists, must be of significance. It is good for teacher to combine several approaches together. Business English teachers are not to teach business people the behavioral techniques of, for example, negotiation, these are better taught, they contend, in the learners' own tongues. However, they pragmatically recognize that effective communication requires behavioral skills, and that these skills are especially important for pre-service learners to acquire. There is no methodology specific for BE courses, the classroom skills and techniques acquired in GE teaching can be usefully employed in the BE classroom. However, Business English teaching emphasizes language output and cultivation of communicative competence. Of all the approaches of foreign language teaching, Hutchinson and Waters (1987) maintain that Communicative Approach is usually thought to be closely related to ESP and widely used in ESP teaching as an effective teaching approach. Generally speaking, the characteristics of Communicative Approach, focusing cultivating students' communicative competence as the ultimate goal of teaching; principle of integrating learning and practice, i.e., according to students' needs, to designate textbooks and teaching syllabus; using language to tell stories, i.e., learning language in compliance with practical communication process, to a large extent, comply with the requirement of Business English teaching and effectively realizes the teaching objectives of Business English teaching. Teaching methodology plays an important role in the process of BE teaching. They explained the reasons like this: they can not only deepen the understanding of professional knowledge and enhance the English proficiency. More importantly, they are allowed to use English freely express their professional knowledge in class. In addition, their English proficiency has built a foundation for bilingual teaching. And they have a strong interest in bilingual learning.

Task-based teaching approach requires teachers set up different tasks for the students to achieve different learning purposes. The basic fabric of a Business English course should be tasks, which caters to the task-based teaching approach fairly well. These tasks must have specific objectives which can be clearly defined at the beginning, and which relate to the student's overall objectives in following the course as well as to his or her level of ability. Teacher should set up the task thoroughly, which is essential in order to get maximum value from it, much time can be wasted if students don't know what they're supposed to do. The teacher should also have the ability to select appropriate tasks depending on the needs of the students in relation to their future jobs.

By this way, the center of classroom transfers from the teacher to the students. Arouse the enthusiasm of the students to learn. The teacher is an observer and becomes a language informant only during the language focus stage.

\subsection{Evaluation System}

Without evaluation system, no curriculum design would be a complete one. Then, what is evaluation? 
Evaluation is a wider term, which entails assessment but includes other process as well. From the result of evaluation, decisions will be made whether the objectives of the curriculum have been achieved or not and if not, where the problems will probably be. After the problems are located, decisions are still needed to make so as to be sure how the curriculum will be modified or altered so as to make it a more effective one. Therefore, evaluation itself is a decision making process. The major reason to carry out assessment and evaluation is to "determine whether learners are progressing satisfactorily or not, and if they are not, to diagnose the cause or causes and suggest remedies" (Nunan, 2005, p. 130).

Evaluation is not simply involved in the final stage of a curriculum design. It exists in the whole process of teaching. Evaluation is intimately tied to the rest of curriculum process. Any changes in other elements of curriculum will possibly affect evaluation. The learner's needs are not always the same. For different groups of learners at different time, their needs are sure to be different, so different objectives will be set for them. If the evaluation system remains, it will lose its real use. So evaluation itself is also a dynamic and recycling process. It exists at every stage of curriculum design, and any changes in this chain will affect other elements in the whole system. Who are responsible for evaluation? Traditionally, when evaluation is mentioned, no one would relate it to anything to do with the learner, and it seems natural that the teachers or the school or the concerned government should be responsible for the evaluation, whereas the learner is only a part of the evaluated. But in a learner-centered curriculum design, evaluation is no longer only concerned with teachers, but also closely related to learners. Self-assessment by learner will provide direct feedback to the whole system, which is better than the teachers' or the designer's own judge. Moreover, learner's self awareness can also be developed through being encouraged to undertake self-evaluation of activities, materials and learning arrangement (Nunan, 2005, p. 132). There are many tools or techniques of evaluation. It can be tests of different sorts, like mid-term test, classroom quiz, and entrance exams; it can also be a questionnaire, an interview or an observation of classroom activities. But the most important point is that the technique selected should be appropriate to the objective of the whole system.

\section{Conclusion}

In conclusion, need analysis is the starting points of course design for Business English learners. Both target needs and learning needs analyses should be done in order to achieve the optimization of $\mathrm{BE}$ course design. There is a gap between the society's needs and the present condition of business English talents. The development and implementation of the need based Business English and the syllabus design can be regarded as highly effective in enhancing the learners' performance and promoting their achievement in Business English learning. Moreover, it was indicated that the participants need a flexible approach to ESP syllabus design which provides practice in both the receptive and productive skills. Consequently, the needs-based syllabus document is expected to reflect their needs in terms of skills at the macro- and micro-level, by selecting and grading "authentic materials" (Cowling, 2007). 


\section{References}

Brown, J. D. (1995). The element of language curriculum: A systematic approach to program development. Boston, MA/Cambridge: Heinle \& Heinle/Cambridge University Press.

Chen, B. B. (2009). A Review of Research on Abroad Need Analysis. Foreign Language Teaching and Research, 2, 125-130.

Cohen, L., Manion, L., \& Morrison, K. (2000). Research Methods in Education. London: Routledge.

Cowling, J. D. (2007). Needs analysis: Planning a syllabus for a series of intensive workplace courses at a leading Japanese company. English for Specific Purposes, 26(4), 426-442.

Dudley-Evans et al. (1998). Developments in English for Specific Purposes: Amulti-disciplinary approach. Cambridge: Cambridge University Press.

Ellis, M., \& Johnson, C. (1994). Teaching Business English. Oxford: Oxford University Press.

Grier, A. S. (2005). Integrating needs assessment into career and technical curriculum development. Journal of Industrial Teacher Education, 42(1), 59-66.

Hutchinson, T., \& Waters. (1987) A. English for Specific Purpose. Cambridge: Cambridge University Press.

Lepetit, \& Cichocki. (2005). Teaching languages to future health professionals: A need assessment. In H. M. Long (Ed.), Second language need analysis. Cambridge University Press, UK.

Nunan, D. (2005). The Learner-centered Curriculum-A Study in Second Language Teaching. Shanghai: Shanghai Foreign Language Education Press.

Richards, J. C. (1984). Language Curriculum Development. RELC Journal, 15, 101-129.

Ruth, M. (1980). Business English Basics: A Programmed Approach. New York: John Wiley \& Sons. 